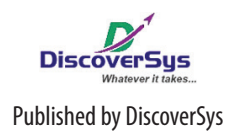

Published by DiscoverSys

\section{Predisposing Factors of the Head of Family with Bali ID Card to Join the National Health Insurance (JKN) Program: A Qualitative Study in Health Centre I North Denpasar}

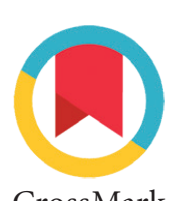

CrossMark

\author{
Cokorda Istri Mita Pemayun, ${ }^{1 *}$ Pande Putu Januraga, ${ }^{2}$ Ni Made Ayu Sri Ratna Sudewi ${ }^{3}$
}

\section{ABSTRACT}

Background and purpose: Since 2010, The Government of Bali has implemented local health financing (JKBM) to provide free health care services for Bali's citizen, meanwhile, since 2014 the central government has started to implement the National Health Insurance program (JKN) based on participant's monthly contribution. Although JKBM still available until 2017, there is a phenomenon of people who have Bali ID card turned into JKN. This article explores predisposing factors of the family head with Bali ID cards so that they switched into JKN scheme with relatively the same medical services and facilities.

Methods: Interviews were conducted with purposively selected participants through the exit interview by using in-depth interview guide to 13 participants of JKN, three region leaders, three participants of JKBM and one public health central officer. Data were analyzed thematically and presented in a narrative form.

Results: The interviews showed that participants who switched to JKN are concerned with sustainability and the quality of services in JKBM program. Participants perceived high vulnerability to disease from previous experience using JKBM program.

Conclusion: Based on the consideration of participants to switch the membership becoming independent JKN Class III, it can be recommended improve the cooperation among stakeholders to enhance the socialization of JKN especially through the involvement of listed participants who already used JKN program.

Keywords: head of the family, KTP Bali (Bali ID Card), Independent JKN Class III

Cite This Article: Pemayun, C.I.M., Januraga, P.P., Sudewi, N.M.A.S.R. 2017. Predisposing Factors of the Head of Family with Bali ID Card to Join the National Health Insurance (JKN) Program: A Qualitative Study in Health Centre I North Denpasar. Public Health and Preventive Medicine Archive 4(1): 48-53. D01:10.15562/phpma.v4i1.56

\title{
Faktor Predisposisi Kepala Keluarga dengan KTP Bali untuk Mengikuti Program JKN Mandiri Kelas III: Studi Kualitatif di Wilayah Kerja Puskesmas I Denpasar Utara
}

${ }^{1}$ Denpasar Health Office,

${ }^{2}$ School of Public Health Udayana University,

${ }^{3}$ Badan Penyelenggara Jaminan Sosial Kesehatan Regional XI Bali Nusa Tenggara

${ }^{*}$ Correspondence to: Cokorda Istri Mita Pemayun, Denpasar Health Office mid.cokp@gmail.com

\section{ABSTRAK}

Latar belakang dan tujuan: Sejak Januari 2010, Pemerintah Provinsi Bali melaksanakan program Jaminan Kesehatan Bali Mandara (JKBM) untuk membiayai pelayanan kesehatan masyarakat ber-KTP Bali yang belum memiliki jaminan kesehatan. Di lain pihak, sejak 1 Januari 2014, Pemerintah Pusat menyelenggarakan program Jaminan Kesehatan Nasional (JKN) dengan sistem iur biaya. Meskipun JKBM masih tersedia hingga tahun 2017, terdapat fenomena masyarakat ber-KTP Bali beralih menjadi peserta JKN mandiri kelas III. Artikel ini mengeksplorasi faktor predisposisi kepala keluarga ber-KTP Bali sehingga beralih menjadi peserta JKN mandiri kelas III dengan fasilitas kesehatan yang relatif sama. Metode: Wawancara dilakukan kepada partisipan yang dipilih secara purposive melalui exit interview dengan menggunakan pedoman wawancara mendalam pada 13 orang partisipan peserta JKN mandiri kelas III, tiga orang pimpinan wilayah, tiga orang partisipan peserta JKBM dan satu orang petugas puskesmas. Data dianalisis secara tematik dan disajikan secara narasi.

Hasil: Wawancara menunjukkan partisipan yang beralih ke JKN merasa khawatir dengan sustainabilitas JKBM, kualitas layanan kesehatan dalam program JKBM dan mempersepsikan kerentanan yang tinggi terhadap penyakit dari pengalamannya memanfaatkan program JKBM sebelumnya.

Simpulan: Berdasarkan pertimbangan partisipan untuk beralih kepesertaan menjadi JKN mandiri kelas III, maka dapat direkomendasikan untuk meningkatkan kerjasama antar stakeholder dalam melakukan sosialisasi JKN, terutama melalui pelibatan peserta yang telah terdaftar dan pernah memanfaatkan program JKN. 
Kata kunci: kepala keluarga, KTP Bali, JKN Mandiri Kelas III

Kutip artikel ini: Pemayun, C.I.M., Januraga, P.P., Sudewi, N.M.A.S.R. 2016. Faktor Predisposisi Kepala Keluarga dengan KTP Bali untuk Mengikuti Program JKN Mandiri Kelas III: Studi Kualitatif di Wilayah Kerja Puskesmas I Denpasar Utara. Public Health and Preventive Medicine Archive 4(1): 48-53. D0I:10.15562/phpma.v4i1.56

\section{PENDAHULUAN}

Kebijakan desentralisasi dan otonomi daerah membuat banyak daerah di Indonesia mengembangkan sistem jaminan kesehatan lokal, salah satunya Pemerintah Provinsi Bali dengan program Jaminan Kesehatan Bali Mandara (JKBM). Program ini memberikan jaminan pembiayaan bagi masyarakat dengan KTP Bali yang belum memiliki jaminan kesehatan dimana sampai tahun 2014 berjumlah sebanyak 2.733 .414 jiwa $(65,91 \%) .{ }^{1}$ Di Kota Denpasar sendiri, jumlah peserta JKBM tahun 2014 sebesar 415.125 jiwa. $^{2}$

Sementara itu, Badan Penyelenggara Jaminan Sosial (BPJS) kesehatan, sejak 1 Januari 2014 sebagai lembaga yang ditunjuk Pemerintah Indonesia mulai melaksanakan program Jaminan Kesehatan Nasional (JKN) yang mencakup kepesertaan Jamsostek, Jamkesmas, Askes PNS, TNI dan Polri serta kepesertaan mandiri. Iuran kepesertaan mandiri kelas I sebesar Rp. 59.500,-, kelas II Rp. 42.500,- dan iuran terendah kelas III sebesar Rp. 25.500,-. ${ }^{3}$ Keberadaan JKN mengharuskan program jaminan kesehatan di tingkat daerah termasuk JKBM diintegrasikan bertahap ke dalam program nasional. Terkait hal ini, Pemerintah Provinsi Bali masih akan memperlakukan program JKBM sampai tahun 2017. Yang menarik adalah terjadi fenomena bahwa ada sebagian kecil masyarakat ber-KTP Bali yang telah beralih menjadi peserta JKN mandiri kelas III yang mengharuskan seluruh anggota keluarga dalam KK untuk membayar iuranbulanan dengan fasilitas kesehatan yang relatif sama dengan JKBM.

Fenomena tersebut jika dipahami dalam konteks pengembangan strategi perluasan cakupan JKN, akan memberikan informasi yang bermanfaat. Artikel ini bertujuan untuk mengetahui faktor predisposisi dari kepala keluarga ber-KTP Bali untuk beralih menjadi peserta JKN mandiri kelas III.

\section{METODE}

Penelitian menggunakan rancangan kualitatif dengan pendekatan fenomenologi. Data yang digunakan adalah data primer yang pengambilannya dilakukan bulan Maret 2015 di wilayah kerja Puskesmas I Denpasar Utara. Lokasi ini dipilih karena tingginya kunjungan kasus penyakit tidak menular (PTM) pada tahun 2014 dibandingkan dengan puskesmas lainnya. Kerentanan terhadap PTM adalah salah satu faktor yang banyak dilaporkan dalam kepesertaan terhadap asuransi kesehatan.

Wawancara dilakukan oleh penulis pertama dengan menggunakan instrumen pedoman wawancara mendalam. Partisipan ditentukan berdasarkan kejenuhan sehingga perekrutan partisipan dihentikan jika tidak ada lagi informasi bermakna yang diperoleh saat wawancara mendalam. ${ }^{4}$ Perekrutan partisipan dilakukan dengan teknik exit interview dimana peneliti melakukan wawancara mendalam dengan kepala keluarga peserta JKN mandiri kelas III yang telah menyelesaikan proses pengobatan rawat jalan di puskesmas. Bila kepala keluarga tidak ikut datang ke puskesmas, peneliti meminta izin untuk bertemu dengan kepala keluarga dan melakukan wawancara mendalam di tempat yang telah disepakati.

Kriteria inklusi partisipan yang direkrut meliputi dapat berinteraksi dan berkomunikasi dengan baik, bersedia menjadi partisipan, kepala keluarga atau anggota keluarga lain sebagai pengambil keputusan untuk menjadi peserta JKN mandiri kelas III yang pernah memanfaatkan program JKBM. Jumlah partisipan peserta JKN mandiri kelas III yang berhasil diwawancarai berjumlah 13 orang. Triangulasi data menggunakan triangulasi sumber melalui wawancara mendalam kepada tiga orang peserta JKBM, tiga orang pimpinan wilayah dan satu orang petugas puskesmas, menggunakan instrumen penelitian yang hampir sama dan disusun oleh peneliti sesuai dengan kebutuhan informasi yang diinginkan dari masing-masing partisipan.

Beberapa item yang dikaji saat wawancara mendalam kepada partisipan peserta JKN mandiri kelas III, diantaranya: sikap dan keyakinan kepala keluarga peserta JKN mandiri kelas III terhadap manfaat kesehatan, sosial ekonomi program JKN dan JKBM, kerentanan terhadap penyakit serta pengalaman saat memanfaatkan program JKBM. Teknik analisis data menggunakan analisis tematik dengan mencari tema penting yang muncul sehingga dapat mendeskripsikan fenomena pada suatu kejadian. ${ }^{5}$ Langkah-langkahnya dimulai dari memberikan kode-kode berdasarkan data dasar yang diperoleh kemudian dilakukan recoding untuk menemukan beberapa kode yang sama sehingga dapat disatukan menjadi sebuah subtema. Subtema dihubungkan pada beberapa tema penting yang 
lebih umum dan dilakukan analisis sesuai teori yang digunakan. ${ }^{6}$ Penelitian mendapatkan ijin dari Badan Perijinan dan Penanaman Modal Provinsi Bali, Kesbanglinmaspol Kota Denpasar, serta persetujuan etik dari Komisi Etik Fakultas Kedokteran Universitas Udayana.

\section{HASIL DAN DISKUSI}

Hasil penelitian pada artikel ini disajikan berdasarkan tema yang diperoleh dari pemberian kode dan penentuan subtema. Dari beberapa tema yang ditentukan, faktor predisposisi yang berkaitan dengan pengambilan keputusan dari kepala keluarga ber-KTP Bali untuk menjadi peserta JKN mandiri kelas III, diuraikan sebagai berikut:

\section{Sikap Terhadap Program JKBM}

Hasil wawancara mendalam dengan partisipan peserta JKN mandiri kelas III menunjukkan adanya kekhawatiran terhadap kualitas layanan JKBM. Selain itu, mereka juga menunjukkan kekhawatiran terhadap manfaat komperhensif JKBM dan sustainabilitas program JKBM. Uraian pernyataannya dapat dituliskan sebagai berikut:

"Kita kan tidak membayar premi di JKBM, jadi kita takut nanti pelayanan di rumah sakit disepelekan oleh petugas, itu yang kita takutkan"

"Kalau untuk JKBM, kan nanti sewaktu-waktu kan bisa berhenti itu... alangkah baiknya mulai sekarang pindah aja ke JKN"

Hasil wawancara mendalam menunjukkan hal yang berbeda dari partisipan peserta JKBM. Mereka masih memiliki keyakinan tinggi bahwa JKBM dapat memberikan fasilitas dan pelayanan kesehatan yang sama dengan JKN mandiri kelas III. Pernyataan partisipan, dituliskan sebagai berikut:

"Kalau JKBMnya berhenti baru saya akan ikut JKN, sepanjang itu sama-sama kelas 3, sepanjang pelayannya sama, seperti apa yang saya dapatkan di JKBM, rasanya lebih gampang menggunakan kartu JKBM itu"

Ungkapan wawancara diatas menunjukkan bahwa rasa khawatir terhadap program JKBM dapat menentukan sikap partisipan dalam pengambilan keputusan untuk menjadi peserta JKN mandiri kelas III. Hal ini sejalan dengan teori determinan prilaku dari Lawrence Green ${ }^{7}$ yang menyatakan bahwa sikap merupakan respon dari emosi individu yang dapat mempermudah adanya perubahan prilaku. Selain menimbulkan perubahan prilaku, respon dari sikap terhadap suatu objek juga dapat memberikan keyakinan kepada seseorang untuk tetap berada pada keputusannya. ${ }^{7}$ Keyakinan peserta JKBM untuk tidak beralih menjadi peserta JKN mandiri kelas III disebakan karena fasilitas rawat inap yang diberikan pada program JKBM sama dengan fasilitas pada program JKN mandiri kelas III yang mewajibkan untuk membayar iuran per bulannya. Hasil penelitian ini juga sejalan dengan penelitian Bukola $^{8}$ yang menyatakan adanya kepercayaan yang tinggi terhadap suatu jaminan kesehatan dapat berpengaruh terhadap kemauan untuk menjadi peserta dalam jaminan kesehatan tersebut.

\section{Sikap terhadap Program JKN}

Disamping rasa khawatir partisipan JKN mandiri kelas III terhadap program JKBM, mereka telah menganggap bahwa kepemilikan JKN mandiri merupakan suatu kebutuhan jaminan kesehatan untuk mengurangi risiko ketika terjadi sakit yang disebabkan karena biaya kesehatan yang semakin meningkat. Uraian pernyataan partisipan, dapat dilihat seperti di bawah ini:

"Disini dah saya lihat banyak masyarakat yang ikut ini, karena kesehatan itu mahal sekali biaya kesehatannya. Jadi masyarakat sekarang lebih memilih untuk BPJS"

Rasa khawatir yang dirasakan dan adanya kesadaran dari partisipan, memberikan keyakinan untuk beralih menjadi peserta JKN mandiri kelas III. Partisipan merasa yakin terhadap program JKN mandiri kelas III karena program JKN merupakan program dari pemerintah yang dapat memberikan tanggungan secara komperhensif kepada masyarakat dan memberikan pelayanan kesehatan yang lebih baik.

"Karena ini program pemerintah, jadi kami jadi percaya gitu, pemerintah berbuat baik untuk rakyatnya, kan ini program pemerintah"

"Ya percaya. Karena bilanglah Bapak pernah dirawat, pelayanannya juga bagus. Dari segi administrasi juga bagus, jadinya saya percaya. Bapak dengan penyakit kronis saja dapat tanggungan"

Hasil penelitian di atas memaparkan bahwa kesadaran pentingnya jaminan kesehatan yang berkesinambungan untuk mengurangi adanya risiko saat terjadi sakit, menjadi pertimbangan dalam pengambilan keputusan menjadi peserta JKN mandiri kelas III. Hal ini dapat memberikan kepercayaan kepada program JKN mandiri kelas III untuk membantu memenuhi kebutuhan 
masyarakat dalam memberikan jaminan kesehatan yang lebih baik sehingga membantu mempercepat pencapaian universal coverage. Hal ini sejalan dengan penelitian Macha, et al bahwa insiatif secara sukarela untuk menjadi peserta jaminan kesehatan merupakan sarana dalam meningkatkan akses pelayanan kesehatan.

Selain itu, keyakinan terhadap banyaknya manfaat yang diperoleh peserta dalam program JKN, juga menjadi pertimbangan oleh peserta untuk beralih kepesertaan ke JKN mandiri kelas III. Manfaat yang diperoleh meliputi manfaat sustainabilitas manfaat komperhensif dan manfaat fleksibelitas. Uraian partisipan, dapat dilihat sebagai berikut:

"Ya daripada kita banyak membuang uang, lebih baik kita menabung seperti ikut BPJS. Istilahnya kita menabung untuk hari tua, mungkin nanti pas tua kita gak bisa kerja atau gimana kan sudah ada tanggungan kesehatan untuk kita"

"Niki kami pernah ada yang sakit terus dirujuk, agak berat obatnya, biaya ditanggung semuanya untuk biaya pengobatannya"

"Iya kalau pas kita ada dana atau lihat situasi di kelas 3 full kamarnya, bisa ke kelas 2 tinggal bayar saja selisihnya, sama pelayannannya.. obatnya juga sama"

Di samping manfaat yang telah diuraikan diatas, mereka juga merasa yakin terhadap keunggulan dari program JKN diantaranya manfaat portabilitas dan adanya prinsip gotong royong. Uraian pernyataan pertisipan terkait hal tersebut, dapat dilihat sebagai berikut:

"JKN bisa digunakan dimana saja, kayak di luar Jawa... kalau JKBM itu kan tanggungan orang Bali aja, dan bisa digunakan di daerah Bali. Tapi kalau JKN itu bisa digunakan dimana saja...Misalnya kita keluar ke Sumatera atau ke Jawa, kita sakit... kita masih bisa menggunakan itu... kartu JKN kelas 3"

"Biaya lebih ringan selain itu kita kan, meskipun kita bayar tiap bulan juga kan untuk orang lain yang lebih membutuhkan meskipun kita gak berharap kita sakit gitu kan nggak mungkin yang kita sumbangin itu bisa untuk orang lain gitu aja"

Pernyataan partisipan diatas, sejalan dengan teori determinan prilaku dari Lawrence Green ${ }^{7}$ bahwa keyakinan merupakan faktor predisposisi yang dapat mempermudah adanya perubahan prilaku, begitu juga dengan penelitian Oriakhi, et $a l^{10}$ menyebutkan bahwa kepercayaan terhadap jaminan kesehatan mempengaruhi kemauan masyarakat untuk menjadi peserta jaminan kesehatan. Keyakinan bahwa program JKN dapat memberikan jaminan pelayanan kesehatan yang berkesinambungan karena iurannya ditanggung bersama oleh semua peserta, dapat memberikan rasa aman sehingga mereka memutuskan beralih menjadi peserta JKN mandiri kelas III.

\section{Kerentanan Terhadap Penyakit}

Pertimbangan lain dari partisipan untuk beralih kepesertaan menjadi JKN mandiri kelas III adalah persepsi terhadap adanya kerentanan penyakit. Uraian pernyataan partisipan, dapat dilihat sebagai berikut:

"Iya karena sekarang mertua punya penyakit ginjal, syukur gitu sudah ikut JKN, jadi kalau dia kumat tiba-tiba sudah ada jaminan, kita tidak terlalu memikirkan masalah biaya dan langsung ditangani"

Berbeda halnya dengan yang disampaikan oleh partisipan peserta JKBM, bahwa mereka merasa tidak atau kurang memiliki kerentanan terhadap penyakit. Pernyataan partisipan dapat dilihat di bawah ini:

"Saya penyakitnya biasa-biasa aja ya, gak terlalu berat, cuma demam, sakit biasa. Nanti kalau sakit kronis gitu, gagal ginjal misalnya stroke gitu, disana mungkin paling pas menggunakan JKN ya karena ditanggung semuanya"

Hasil penelitian menunjukkan partisipan peserta JKN mandiri kelas III banyak yang memiliki keluarga dengan penyakit kronis dan rentan terhadap penyakit parah sehingga bersedia menjadi peserta JKN mandiri kelas III. Pernyataan ini sejalan dengan penelitian Macha, et al $l^{9}$ menyatakan bahwa status kesehatan yang buruk dan rentan menjadi sakit berkaitan dengan kesediaan masyarakat untuk menjadi peserta jaminan kesehatan.

Penelitian oleh Mhere $^{11}$ juga mendukung pernyataan di atas bahwa anggota keluarga yang memiliki penyakit kronis bersedia untuk menjadi peserta jaminan kesehatan. Hal ini didukung oleh teori protection motivation and self efficacy dari Rogers ${ }^{12}$ yang merupakan efek fear appeals untuk mempengaruhi, melalui ancaman atau bahaya yang berisiko terjadi pada diri seseorang sehingga dikatakan efektif dalam menghasilkan perubahan sikap dan telah digunakan dalam upaya mengubah perilaku seseorang. 


\section{Pengalaman Memanfaatkan JKBM}

Hasil wawancara mendalam memaparkan bahwa pengalaman memanfaatkan jaminan kesehatan sebelumnya berkaitan dengan keputusan dalam memilih suatu jaminan kesehatan. Peserta JKN mandiri kelas III menyatakan prosedur administrasi JKBM dirasa lebih sulit dan pelayanan yang diberikan tidak komperhensif. Pernyataan partisipan dapat dituliskan seperti di bawah ini:

"Prosedur JKBM terlalu ribet untuk mendapatkan pelayanannya. Kadang-kadang capek ngurus itu aja, bolak-balik terus jadinya susah"

"Kemarin saudara saya itu sempat operasi usus buntu, cuma tidak semuanya ditanggung, sama kemarin yang kecelakaan itu maunya pakai JKBM, nggak bisa dipakai JKBM ternyata"

Hasil penelitian di atas menunjukkan bahwa peserta JKN mandiri kelas III mengalami kesulitan dalam proses administrasi saat memanfaatkan program JKBM dan pelayanan yang diberikan tidak komperhensif. Hal ini disebabkan karena banyaknya persyaratan yang diperlukan terutama saat ingin mendapatkan pelayanan di rumah sakit. Selain itu, pembatasan cakupan tanggungan JKBM juga menjadi pertimbangan peserta untuk beralih kepesertaan menjadi JKN mandiri kelas III.

Pernyataan di atas sejalan dengan penelitian Barnighausen et $a l^{13}$ bahwa pengalaman dalam mendapatkan pelayanan kesehatan di masa lalu mempengaruhi kemauan masyarakat untuk menjadi peserta dan membayar iuran jaminan kesehatan. Teori pendukung dari hasil penelitian ini adalah teori Kurt Lewin ${ }^{14}$ yaitu pada tahap moving/ changing dan refreezing menyatakan ketidakpuasan pada kondisi saat ini menyebabkan adanya keinginan untuk membuat beberapa perubahan dan membiasakan adanya perubahan tersebut, yang dalam hal ini adalah pengalaman tidak memuaskan terdahulu dalam memanfaatkan program JKBM mendukung untuk beralih menjadi peserta JKN mandiri kelas III.

Berbeda halnya dengan yang dirasakan peserta JKBM bahwa proses administrasi untuk mendapatkan pelayanan di JKBM sangat mudah dan pelayanan yang diberikan juga sangat baik. Uraian pernyataan partisipan dapat dilihat sebagai berikut:

"Administrasinya cukup lancar, sama sekali tidak dipersulit jadi sebagai masyarakat saya bersyukur. Kemudian tidak ada pembedaan pelayanan baru gratis pelayanannya terakhir... Tidak.., sangat bagus"
Disisi lain ternyata partisipan peserta JKBM hanya pernah memanfaatkan program JKBM di puskesmas untuk penanganan penyakit yang ringan dan belum sampai pada perawatan di rumah sakit. Pernyataan partisipan, dapat dilihat sebagai berikut:

"Kalau sakit parah sih saya belum merasakan langsung dan juga belum pernah ada keluarga yang sakit parah, jadi saya lebih cenderung ke JKBM di puskesmas. Karena waktu itu saya memanfaatkan untuk imunisasi anak dan sakit ringan-ringan aja"

Hasil penelitian diatas menunjukkan bahwa partisipan peserta JKBM belum memiliki pengalaman tentang pemanfaatan fasilitas rawat inap pada program JKBM di rumah sakit karena JKBM dianggap masih cukup dalam memenuhi kebutuhan jaminan kesehatannya sampai saat ini sehingga belum perlu beralih menjadi peserta JKN mandiri kelas III. Hal ini sejalan dengan penelitian Bukola $^{8}$ yang menyatakan bahwa pengalaman terdahulu ketika memanfaatkan jaminan kesehatan berpengaruh terhadap kemauan masyarakat untuk bertahan pada kepesertaan jaminan kesehatan, dalam hal ini pengalaman yang hanya sebatas di Puskesmas sehingga partisipan bertahan dalam kepesertaan JKBM.

\section{Pengalaman Memanfaatkan JKN}

Hasil wawancara mendalam menunjukkan bahwa partisipan peserta JKN mandiri kelas III merasakan kemudahan selama memanfaatkan program JKN mandiri kelas III baik dari segi administrasi, portabilitas, pelayanan kesehatan dan manfaat komperhensifnya. Uraian pernyataan partisipan dapat dipaparkan di bawah ini:

"JKN itu lebih mudah, terus...kita harus membayar premi setiap bulannya, terus istilahnya kita... kalau misalnya kita sakit itu bisa digunakan dimana saja terus persyaratannya tidak terlalu sulit dan juga berapa pun biaya yang kita gunakan itu terbayarkan. Jadi kita bisa mendapatkan pelayananan yang semaksimal mungkin lah"

Berdasarkan uraian pernyataan di atas, partisipan peserta JKN mandiri kelas III memiliki pengalaman yang positif dalam pemanfaatkan program JKN. Hal ini sejalan dengan penelitian Jehu-Appiah ${ }^{15}$ bahwa pengalaman positif tentang kemudahan layanan berkaitan dengan kemauan masyarakat untuk mempertahankan keputusannya memilih jaminan kesehatan. 
Pembahasan pada artikel ini hanya dalam ruang lingkup faktor predisposisi yang menyebabkan kepala keluarga ber-KTP Bali beralih menjadi peserta JKN mandiri kelas III. Untuk itu, stakeholder terkait disarankan melakukan sosialisasi yang lebih intensif dan meningkatkan kualitas layanan kesehatan sehingga seluruh masyarakat sadar akan pentingnya jaminan kesehatan serta segera beralih menjadi peserta JKN mandiri.

\section{SIMPULAN}

Faktor predisposisi dalam pengambilan keputusan untuk beralih menjadi peserta JKN Mandiri kelas III meliputi sikap khawatir terhadap kualitas layanan, manfaat komperhensif dan sustainabilitas program JKBM. Selain itu, adanya kerentanan terhadap penyakit yang tidak ditanggung dalam program JKBM dan pengalaman masa lalu ketika memanfaatkan program JKBM juga menyebabkan masyarakat beralih menjadi peserta JKN mandiri kelas III. Artikel ini diharapkan dapat memberikan masukan kepada pemegang kebijakan dan pemberi pelayanan kesehatan dalam pengembangan strategi yang tepat dalam upaya meningkatkan kualitas layanan program JKN.

\section{UCAPAN TERIMA KASIH}

Ucapan terima kasih penulis sampaikan kepada seluruh partisipan pada penelitian ini dan jumantik Puskesmas I Denpasar Utara.

\section{DAFTAR PUSTAKA}

1. Pemerintah Provinsi Bali. Pedoman Penyelenggaraan Program Jaminan Kesehatan Bali Mandara. 2nd ed. Denpasar: Dinas Kesehatan Provinsi Bali; 2014.
2. Pemerintah Kota Denpasar. Surat Keputusan Walikota Denpasar Nomor 188.45/236/HK/2013; 2013.

3. Peraturan Presiden Republik Indonesia. Peraturan Presiden Republik Indonesia Nomor 12 Tahun 2013 Tentang Jaminan Kesehatan; 2013.

4. Bungin BPDD. Metode Penelitian Kualitatif; Aktualisasi Metodelogis Ke Arah Ragam Varian Kontemporer. 1st ed. Jakarta: PT. Rajagrafindo Persada; 2012.

5. Fereday J. Demonstrating Rigor Using Thematic Analysis : A Hybrid Approach of Inductive and Deductive Coding and Theme Development. 2006;80-92.

6. Sastroasmoro S. Dasar - Dasar Metodelogi Penelitian Klinis. 4th ed. Jakarta: Sagung Seto; 2011.

7. Notoatmodjo S. Promosi Kesehatan; Teori Dan Aplikasi. Edisi Revi. Jakarta: PT. Rineka Cipta; 2010.

8. Bukola A. Willingness to Pay For Community Based Health Care Financing Scheme: A Comparative Study among Rural and Urban Households in Osun State , Nigeria. 2013;5(6):27-40.

9. Macha J, Kuwawenaruwa A, Makawia S, Mtei G, Borghi J. Determinants of community health fund membership in Tanzania: a mixed methods analysis. BMC Health Serv Res [Internet]. 2014 Nov 20 [cited 2015 Jan 10];14(1):538.

10. Oriakhi. et all. Determinants of Rural Household's Willingness to Participate in Community Based Health Insurance Scheme in Edo State, Nigeria. 2012;6(2):95-102.

11. Mhere F. Health insurance determinants in Zimbabwe: Case of Gweru Urban. 2013;14 (October 2009):62-80.

12. Maddux JE, Rogers RW. Protection motivation and self-efficacy: A revised theory of fear appeals and attitude change. J Exp Soc Psychol [Internet]. 1983 Sep;19(5):469-79.

13. Barnighausen et all. Willingness to pay for social health insurance among informal sector workers in Wuhan, China: a contingent valuation study. BMC Health Serv Res [Internet]. 2007 Jan [cited 2014 Sep 19];7:114.

14. Wirth RA. Lewin/Schein's Change Theory. 2004;1-2.

15. Jehu-Appiah C, Aryeetey G, Agyepong I, Spaan E, Baltussen R. Household perceptions and their implications for enrollment in the National Health Insurance Scheme in Ghana. Health Policy Plan [Internet]. 2012 May [cited 2014 Dec 25];27(3):222-33.

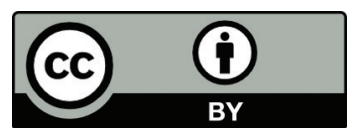

This work is licensed under a Creative Commons Attribution 